\title{
Jury verdicts: Comparison of 6- vs. 12-person juries and unanimous vs. majority decision rule in a murder trial
}

\author{
ROBERT BUCKHOUT, STEVE WEG, VINCENT REILLY, and ROBINSUE FROHBOESE \\ Center for Responsive Psychology, Brooklyn College, City University of New York, \\ Brooklyn, New York 11210
}

\begin{abstract}
A total of 180 jurors from the Kings County, New York, Jury Assembly room served as mock jurors in a murder trial presented on videotape. Subjects were randomly assigned to cells of a 2 by 2 design which varied jury size (6 vs. 12) and verdict decision rule (majority vs. unanimous). An ANOVA showed that jury verdicts became more severe as a result of deliberating in the smaller jury and under majority rule. The majority decision rule clearly resulted in more convictions. Empirical support for the smaller size jury effect was limited.
\end{abstract}

The U.S. Supreme Court is hesitantly looking to social scientists to provide empirical data on which major decisions affecting jury trials can be based. Regretably, the court is not finding much data, either because the research has not been done or because some of the available research data are not adequate (Buckhout, Note 1). In the dubious search for efficiency, many state court systems have moved to the use of 6-person as opposed to 12-person juries and are experimenting with a relaxation of the unanimous decision rule in favor of a majority (usually 5/6) decision rule. Several challenges to these rule changes have arrived in the Supreme Court, and neither psychology nor the law has looked all that good in the written opinions of the court.

The Supreme Court has displayed a profound ignorance of the meaning and value of empirical research in its recent decisions affecting juries. In Apodaca et al. vs. Oregon (1972) and Johnson vs. Louisiana (1971), the court studied the question of the obligation of the states to provide for a unanimous verdict in criminal trials, as opposed to some majority decision rule. The court held that, in other than federal cases, the unanimous decision rule is not guaranteed under the Constitution and, hence, may be left to the discretion of the states to establish. Justice Douglas, in a fierce dissenting opinion, argued that the Court ignored the fact that nonunani-

Reprints and background information, including a full transcript of the trial, may be obtained from the senior author at the Center for Responsive Psychology, Brooklyn College, CUNY, Brooklyn, New York 11210. An early report of this research was presented to the Eastern Psychological Association, New York, April 15, 1975. This research was supported (in part) by a grant from the Faculty Research Award Program of the City University of New York. Robinsue Frohboese is now at the Law-Psychology Program, University of Nebraska-Lincoln, 209 Burnett Hall, Lincoln, Nebraska 68508. mous juries convict about twice as often as unanimous juries do.

An equally fundamental question was raised in Williams vs. Florida (1970) and Colgrove vs. Battin (1973) concerning the right to trial by a 12 -member jury. Here the Court similarly held that the size of a jury, in other than federal cases, is not guaranteed. In both instances the Court's conclusions were based on the presumption that changes in neither decision rule nor jury size would, in and of themselves, affect conviction rates. Both conclusions were drawn in the absence of firm empirical evidence, relying heavily on the data and opinions found in that wide-ranging, now classic book, The American Jury, by Kalven and Zeisel (1966) plus some law review articles (Berman \& Coppock, 1973; Kessler, 1973; Mills, 1973).

Kalven and Zeisel pinpoint the nature and hazards of the type of study relied upon by the Court quite succinctly. In its optimal form, they explain, "It can be viewed as simply a retrospective controlled experiment. The cases are grouped after the fact by the critical variable to see if the variable has produced a difference .... The logic is precisely the same as for the experiment, except for one important and in the end ineradicable difficulty; one can never be sure that the groups of cases to be compared are comparable in all respects other than the critical variable" (pp. 89-90).

Zeisel (1974) bitterly criticized the Supreme Court for its statistical ignorance of the fact that "the smaller the size of the sample, the larger the margin of error." Further, he notes that smaller juries mean less representativeness of the community in seated juries. Saks (1974) noted that some of the studies cited in Colgrove actually reported data opposite to the interpretations made by the Court. His criticism, directed at both psychologists and lawyers, was ably summed up as follows: "The fact that reliable empirical evidence on these questions is lacking is largely the fault of social 
scientists who are insufficiently knowledgeable about the law to know what data the law needs. And the agents of the law are such strangers to empirical methods of understanding behavior they cannot tell that they have not been provided with the necessary empirical data."

More recently, Davis, Kerr, Atkin, Holt, and Meek (1975) reported no significant differences among student mock jury verdicts as a function of either size or decision rule. Valenti and Downing (1975) reported that, in prosecution-oriented cases, 6-person juries were more likely to convict than 12-person juries. Grofman (Note 2) reanalyzed the Valenti and Downing data, noting that the predeliberation verdicts of the 6-person juries were closer to a conviction than the 12-person juries. Grofman relegates the Valenti and Downing findings to inadequately controlled sampling, a problem exacerbated by the limited overall sample size.

Despite the absence of clear-cut empirical support, social scientists (e.g., Gelfand, 1977) maintain that the mathematics of the group sizes in a jury would force more decisions with a smaller jury and hence more convictions, since approximately $83 \%$ of all criminal juries convict (Kalven \& Zeisel, 1966). Lempert (1975) points out that to detect a difference due to size would require a prohibitively large number of juries and he speculates on the possibility that the Supreme Court has contented itself with data which might mask a Type II error.

Our experiment suffers from some of the same problems noted above, since the sample size is limited. We ambitiously set out to compare the effects of jury size and decision rule in the real world-in a jury assembly room. Unfortunately, the Court withdrew permission for the research after we had tested a total of 20 juries in a 2 by 2 design. Comparing 6-vs. 12-person juries under a unanimous vs. majority decision rule, we tested whether a shift in procedure would affect jury verdicts. We offer these findings as an aid to other researchers who might gain from our experience under more favorable test conditions.

\section{METHOD}

\section{Subjects}

A total of 180 jurors from the Jury Assembly in the Kings County, New York, Supreme Court were randomly assigned by the jury clerk to serve as mock jurors in the trial (as done for actual trials). The characteristics of the sample group matched the demographic profile of New York City jurors very closely. They were near the end of their 2-week term and were given the option of remaining in or leaving the experiment.

\section{Procedure}

The mock jurors completed demographic questionnaires. Each then read a brief summary of the case he would have to judge to compensate for the relative brevity of the videotaped presentation which was to follow. It was deemed important that the "facts" of the case be understood and that a preliminary briefing as to the testimony the jurors would hear would facili- tate comprehension. Juror numbers were randomly assigned to each person, resulting in their assignment to an experimental condition.

Following the reading of the case summary, jurors viewed a videotaped presentation of a "mock" murder trial. In this case the defendant is accused of committing murder during the attempted commission of a robbery. The case, adapted from Vidmar (1972), is constructed in such a way that questions as to guilt arise from gross differences in the testimony of witnesses. Modifications allowing for locale (the original case was heard in Canada) were made. Furthermore, as no transcript was available, a script was extrapolated for use in the videotaping. In doing so, certain liberties were taken in adpating the case for dramatic presentation, in order to optimize the ambiguous nature of the testimony. Included in the script were the standard judge's instructions (New York State) concerning evidence and reasonable doubt, summations by prosecutor and defense attorney, and a final charge by the judge.

The presentation itself was taped on $1 / 2$-in. black-white videotape and ran $32 \mathrm{~min}$ in length. Actual technical production was handled by the Brooklyn College Television Center. Taping was done with three ceiling-mounted television cameras in a small studio. Three separate microphones were placed around the studio to pick up the audio of all participants. The studio was equipped with an isolated control room. Actors were nonprofessional and consisted of a group of Brooklyn College students and psychology faculty members.

After viewing the videotaped presentation, subjects completed predeliberation verdict questionnaires. This was done to provide data on decision changes during the deliberation process. The option of verdicts available to the jurors were as follows: (1) guilty of first-degree murder, (2) guilty of second-degree murder, (3) guilty of reckless manslaughter, (4) guilty of negligent manslaughter, (5) not guilty. (Options 2-4 were lesser included verdicts.) The nature and definition of each of these charges were included in the questionnaire. They were also explained by the judge in her charge to the jury (the final segment of the videotaped presentation).

Allowing the jurors to decide the actual charge of the "guilty" verdict is not standard legal procedure in most jurisdictions, although in specified areas today, as well as historically, such practice has been made. More typically, the jury would only decide guilt or innocence of a single charge, specified by the court. In choosing the atypical procedure, two considerations were kept in mind. The first of these was that the greater sensitivity of this measure of verdict severity seemed desirable. Jurors differ in terms of how strongly they feel about their verdicts, and a simple "guilty/not guilty" measure would not expose these differences. Second, as the script of the mock trial has not been used previously in this context, there was no way of knowing which verdicts to expect. While ambiguity was emphasized, any quirks in the transcript might have swayed the verdicts too much in one direction to reasonably allow for choice on the parts of the jurors.

Following completion of the predeliberation verdict questionnaires, the juries were left unobserved to deliberate and arrive at group verdicts, according to the instructions from the experimenter concerning decision rules.

Subjects were assigned to one of four conditions. Assignment was made to either 12 or 6 juries, under decision rules of either unanimity or $5 / 6$ quorum. There were 20 mock juries, with 5 juries in each of the following conditions: (1) 12 -member juries, under a unanimous decision rule; (2) 12-member juries, under a $5 / 6$ quorum decision rule; (3) 6-member juries, under a unanimous decision rule; (4) 6-member juries, under a $5 / 6$ quorum decision rule. Instructions as to what would constitute a final verdict for a particular jury (i.e., the decision rule) were given by the experimenter, rather than by the judge (as would normally occur in a real trial).

Following deliberations, each juror completed a final questionnaire, asking for his jury's verdict, as well as for his indi- 
vidual verdict. Once again the nature and definition of each charge was included on the form.

\section{RESULTS}

\section{Decision Rule and Verdicts}

By assigning scores of 1 through 5 (guilty through not guilty), we determined the mean verdict for each jury averaged over the five juries in each cell of the design. There were no significant differences in predeliberation verdict $(F=.71,3.06, .59 ; \mathrm{df}=1 / 16)$. The main dependent variable results, final jury verdicts of all 20 juries under the unanimous and nonunanimous verdict rules, are shown in Table 1 . Under the unanimous verdict decision rule, there were only three convictions and seven hung juries, an outcome which may be regarded as the normally expected or control outcome by typical jurors in reaction to the weight of evidence in this particular trial. Changing the decision rule to a $5 / 6$ or $10 / 12$ majority rule resulted in nine (or three times as many) convictions, a finding which was highly significant $(Z=4.29, p<.001)$. Two of the six-person juries voted to convict the defendant of second-degree murder under the nonunanimous verdict rule. Only one nonunanimous rule jury reported that it was deadlocked.

\section{Jury Size and Verdicts}

In Table 2, in a comparison of all 6-person and 12-person juries, the number of convictions was the same, but the severity of the final verdicts was somewhat higher in 6-person juries. The small number of juries tested contributed to a lack of statistical significance in the testing of the size variable. The combination of a nonunanimous verdict rule in a 6-person jury produced $100 \%$ convictions.

Table 1

Final Jury Verdicts as a Function of Decision Rule

\begin{tabular}{lcc}
\hline & \multicolumn{2}{c}{ Decision Rule } \\
\cline { 2 - 3 } Convictions & Unanimous & $\begin{array}{c}\text { Non- } \\
\text { unanimous* }\end{array}$ \\
\hline Second-Degree Murder & 3 & 2 \\
Reckless Manslaughter & 3 & 6 \\
Negligent Manslaughter & & 1 \\
Hung Juries & 7 & 1 \\
\hline
\end{tabular}

*5/6 or $10 / 12$

Table 2

Final Jury Verdicts as a Function of Jury Size

\begin{tabular}{lcc}
\hline & \multicolumn{2}{c}{ Jury Size } \\
\cline { 2 - 3 } Convictions & 6-Person & 12-Person \\
\hline Second-Degree Murder & 2 & \\
Reckless Manslaughter & 3 & 6 \\
Negligent Manslaughter & 1 & \\
Hung Juries & 4 & 4 \\
\hline
\end{tabular}

Table 3

Analysis of Variance of Changes from Pre- to Post-Verdicts Due to Deliberation by Juries in a Metropolitan Supreme Court

\begin{tabular}{lrrl}
\hline \multicolumn{1}{c}{ Source } & df & MS & \multicolumn{1}{c}{ F } \\
\hline Jury Size (s) & 1 & .8799 & $6.479^{*}$ \\
Verdict Rule (V) & 1 & .9598 & $7.067^{*}$ \\
S by V & 1 & .4148 & 3.055 \\
Error & 16 & .1358 & \\
Total & 19 & & \\
\hline
\end{tabular}

${ }^{*} p<.05 \quad$ Note-Mean shift: 6-person juries, -.191; 12-person juries, +.228; unanimous juries, +.238; nonunanimous juries, -.200 .

\section{Effects of Deliberation}

Using the recorded verdict prior to the start of deliberation, the mean predeliberation verdict was computed for each jury in each cell of the experimental design. The average overall pre-verdict was 3.05 , which averages out to conviction for reckless manslaughter with only a few votes for acquittal. The focus of the deliberations was destined to be on which of the levels of "guilty" would be voted for. To evaluate the effects of deliberating under variations in jury size and verdict rule, a 2 by 2 analysis of variance on the differences between mean predeliberation and mean postdeliberation individual verdicts for each jury was computed (see Table 3 ). The main effects of both verdict rule and jury size were significant $(p<.05)$. In the case of jury size, the change in mean jury verdict was toward a more severe verdict in the 6-person condition and toward a less severe verdict in the 12-person condition. The nonunanimous decision rule produced a mean shift toward the more severe verdict, while the unanimous decision rule effected a shift toward a less severe verdict $(p<.05)$. The interaction mean square fell short of significance. The importance of these deliberation effects can be better understood in light of the fact that, as expected, the final individual verdicts were significantly correlated with the pre-verdicts $(\mathrm{r}=.54$, $\mathrm{p}<.001$ ), though the relationship accounts for only $29 \%$ of the variance.

\section{DISCUSSION}

It is important to review at this point the fact that we attempted to conduct this study in the real world of a State Court jury assembly room in order to approximate the realism of jury trials as closely as practicable. Our mock trial was something that ordinary jurors were randomly assigned to, just as they would be assigned to any other trial. While we did not have the voir dire screening and selection by lawyers common to a real trial, the resulting demographic profile of our jurors showed them to be markedly similar to the typical juror who serves in the court in which we worked. Of course, they lacked the sense of urgency and involvement that a juror feels when he has a real defendant's life in his hands, but we were pleased to find that the jurors took the deliberations seriously and argued strongly for their points of view. Unfortunately, as happens in the real world, our research was cut short by the decision of an administrative judge who feared that our research might cause 
the jurors to think about their roles and in some way affect their later performance as jurors in real trials.

The results of this experiment clearly confirm the hypothesis that a change in decision rule from unanimous to a majority verdict is conducive to a greater number of convictions by criminal trial juries in the face of the same trial and the same evidence. The results provided only partial support for the predicted effects of reducing jury size from 12 to 6 persons. The number of convictions was the same, but the 6-person juries brought in more severe (second-degree murder) verdicts in two instances. These are the most important findings from the standpoint of the relevant Supreme Court decisions, supplying some of the "missing" empirical data noted in the dissent opinion of Justice Douglas (U.S., Johnson vs. Louisiana, 1971).

In the present study, the 12-person or the unanimous verdict conditions are the "control" conditions against which to judge the results. In the case of a unanimous verdict, the most likely outcome of this trial would have been a hung jury. But the majority $(5 / 6$ or $10 / 12)$ verdict rule clearly was more advantageous to the prosecution in that more convictions resulted.

Since the intent of the Supreme Court is that neither the state nor the defendant should gain advantage from a mere change in procedure, it is clear that the Court has incorrectly concluded that variations in size or decision rule have no effect on judicial finding. The anecdotal discussions of the Justices may now be supplemented by at least some hard data which support the proposition that both the 12-person jury and the unanimous verdict rule should be retained in criminal trials.

\section{REFERENCE NOTES}

1. Buckhout, R. The U.S. Supreme Court vs. social Science: The jury (Report No. CR-28). Brooklyn, N.Y: Brooklyn College, Center for Responsive Psychology, April 1977.

2. Grofman, B. Personal communication, February 16, 1977.

3. Buckhout, R., Weg, S., Frohboese, R., \& Reilly, V. Jury verdicts: Six vs. 12 person juries, unanimous vs. majority decision rule in a murder trial (Report No. CR-12). Brooklyn, N.Y: Brooklyn College, Center for Responsive Psychology, April 1977.

\section{REFERENCES}

Apodaca et al. vs. Oregon, 406 U.S. 404, 1971.

Berman, G., \& Coppock, R. Outcomes of six and twelve member jury trials: An analysis of 128 civil cases in the State of Washington. Washington Law Review, 1973, 48, 593-596.

BucKhout, R., ET AL. Jury without peers. In M. Reidel \& P. A. Vales (Eds.), Treating the offender: Problems and issues. New York: Praeger, 1977.

Colgrove vs. Battin, 413 U.S. 149, 1973.

Davis, J. H., KerR, H. L., Atkin, R. W., Holt, R., \& MeEk, D. The decision processes of 6- and 12-person mock juries assigned unanimous and $2 / 3$ majority rules. Journal of Personality and Social Psychology, 1975, 32, 1-14.

Gelfand, A. E. A statistical case for the twelve-member jury. Trial, 1977, 13, 41-42.

Johnson vs. Louisiana, 406 U.S. 813, 1971.

Kalven, H., JR., \& Zeisel, H. The American jury. Boston: Little, Brown, 1966.

Kessler, J. An empirical study of six- and twelve-member jury decision-making process. University of Michigan Journal of Law Reform, 1973, 6, 712-734.

LEMPERT, R. O. Uncovering "nondiscernible" differences: Empirical research and the jury size cases. Michigan Law Review, 1975, 73, 643-708.

Mills, L. R. Six member and 'twelve member juries: An empirical study of trial results. University of Michigan Journal of Law Reform, 1973, 6, 671-711.

SAKs, M. J. Ignorance of science is no excuse. Trial, 1974, 10, 18-20.

Valenti, A., \& Downing, L. Differential effects of jury size on verdicts following deliberation as a function of apparent guilt of the defendant. Journal of Personality and Social Psychology, 1975, 32, 655-663.

VIDMAR, N. Effects of decision alternatives on the verdicts and social perceptions of simulated jurors. Journal of Personality and Social Psychology, 1972, 22, 211-218.

Williams vs. Florida, 399 U.S. 78, 1970.

ZeISEL, H. Twelve is just. Trial, 1974, 10, 13-15.

(Received for publication May 3, 1977.) 